\title{
Investor's Mood at ASIAN Games Event
}

\author{
Happy Sista Devy', Bahrain Pasha Irawan² \\ IAIN Pekalongan ${ }^{1}$, UNISSULA Semarang ${ }^{2}$
}

happy.sista.devy@iainpekalongan.ac.id ${ }^{1}$, bahrainpasha@gmail.com ${ }^{2}$

\begin{abstract}
Goals of the research to analyze whether occurred abnormal return of ASIAN Games phenomena and see how investors react to the big ASIAN Games 2018 event in Indonesia. . This reseach uses a sample of companies included in the hotel, restaurant and tourism sub-sector on the Indonesia Stock Exchange (IDX) during the observation period, based on the purposive sampling method which obtained 22 companies and used the event study method. There is a significant abnormal return but not on the phenomenon of the Asian Games 2018. This shows that investors still wait and see to the organization of the Asian Games in 2018. No difference of abnormal return before and after the Asian Games 2018. This is because, as investors look to the many tourists who have started to flock to Indonesia before the Asian Games in 2018 took place.
\end{abstract}

Keywords: abnormal return, ASIAN GAMES 2018, event study.

\section{Abstrak}

Tujuan dari penelitian ini adalah untuk menganalisis apakah terjadi abnormal return atas fenomena ASIAN Games dan melihat bagaimana reaksi investor mengenai adanya event besar ASIAN Games 2018 di Indonesia. Penelitian ini menggunakan sampel perusahaan yang termasuk dalam sub sektor hotel, restoran dan pariwisata di Bursa Efek Indonesia (BEI) selama periode pengamatan, berdasarkan metode purposive sampling didapat 22 perusahaan dan menggunakan metode event study. Hasil penelitian ini menunjukkan terdapat abnormal return tetapi tidak signifikan atas fenomena ASIAN Games 2018. Hal ini menunjukkan bahwa investor masih wait and see terhadap penyelenggaraan ASIAN Games 2018. Tidak terdapat perbedaan abnormal return sebelum dan sesudah penyelenggaraan ASIAN Games 2018. Hal ini terjadi karena investor melihat banyaknya wisatawan yang sudah mulai berdatangan ke Indonesia jauh sebelum penyelenggaraan ASIAN Games 2018 berlangsung.

Kata Kunci: abnormal return, ASIAN Games 2018, event study.

\section{INTRODUCTION}

The Stock Exchange or Stock Market is a tool for increasing long-term asset to development projects and or a business in order to have a growth (Lim \& Downward, 2009). Several facilities which provided in the stock exchange are trading for the company and investor to sell and buy shares or securities. Running the capital market, there are many components in the form of element or influence of the capital market development. One of the most important elements in the capital market is all information relating with company or macroeconomic information in a country. The existence of this information would make the investor believes that all the necessary 
information is available and all the mechanisms in the capital market can be trusted. There is no side could manipulate these information. Fama (1970) mentioned a theory about effecienctmarket hypothesis (EMH) which makes grouping form of the market efficiency, including is weak form, semi-strong form, and strong form. The theory about market efficiency, there are phenomena that becomes market anomalies in the capital market. Market anomalies that happened due to there is an event or phenomena which should not be occur if a capital market is in the efficient (Rusdianrto yanuar, 2014). Several phenomena that become the information to the shareholder or market particiant including the international sports that participated by throughout the world.

One of the phenomena that occurred the sports event Asian Games which participated by the athletes all Asian countries. Asian Games 2018 is participated by 45 Asian countires, such as Afganistan, Bahrain, Bangladesh, Bhutan, Brunei, Cambodia, China, Taipei, Hong Kong, India, Indonesia, Iran, Iraq, Japan, Jordan, Kazakhstan, Kuwait, Kyrgyzstan, Laos, Lebanon, Macau, Malaysia, Maladewa, Mongolia, Myanmar, Nepal, Korea Utara, Oman, Pakistan, Palestina, Filipina, Qatar, Arab Saudi, Singapura, Korea Selatan, Sri Lanka, Syria, Tajikistan, Thailand, Timor Leste, Turkmenistan, Uni Emirat Arab, Uzbekistan, Vietnam, and Yemen. The Asian Games in 2018 which host is Indonesia. Indonesian people are very enthusiastic about the existence of this four-year sport event, in this year Asian Games held on 18 August until 2 September 2018. This sport event is concerned to many Asian people, including. In 2018, Indonesia became the host of this Asian sports event, this became a focus to all Indonesian parties to prepare every single things that are necessary, including venue, hotel, or lodging for athletes, and public facilities that would be used in this largest Asian sport event. The existence of this sporting competition makes the attraction to many countries to attend or see and support this Asian Games event. Because there are many Asian countries visit Indonesia makes Indonesia optimistic show several tourisms, hotels, and restaurants which can be relied in Asian countries.

The research that conducted by Kaplanski \& Levy (2008) that saw the effect of Fifa world cup event in the stock market located in United States, showed the result during the research period there were abnormal return of $-2,58 \%$. This research result showed the prove that the existence of fifa world cup event gave the psychological effect on investor in United (Kaplanski \& Levy, 2008). The testing of phenomena that occurred globally or international is also conducted by Pratiwi \& Yusuf (2015). This research result showed that the information of world cup 2014 had the meaningful to investors. In phenomena of world cup 2014 showed influence to investor in Indonesia and Thailand, so causing a reaction to stock market (Pratiwi \& Yusuf, 2015). The research that used data to fifteen countries that had done by Ehrmann 7 Jansen (2017), found out that activity of market has decreased during FIFA match event in 2010, it the same with when lunch time, and the result does not give effect to the theory. The result of the study dedicated that either 
national or international sports event could affect stock prices. However, the different result conducted by the research of Vieira (2012) which showed that there is no directly the relation between sports event especially world cup to the stock prices, the event did not make the shareholders sentiment with certain activities in their respective countires became affected in managing their shares. The same result showed by the study of Ehrmann, M., \& Jansen, D. J. (2017) that found out that there was no the investor concern to FIFA world cup event, so that there were no occur abnormal return even after or before the event. In addition, there was the differences in the research result or research gap that occured before, it seems there is fluctuating data on stock return condition. The data bellow showed the average stock return in the time when ASIAN Games 2018 held on :

Picture 1.1 The average of stock Return

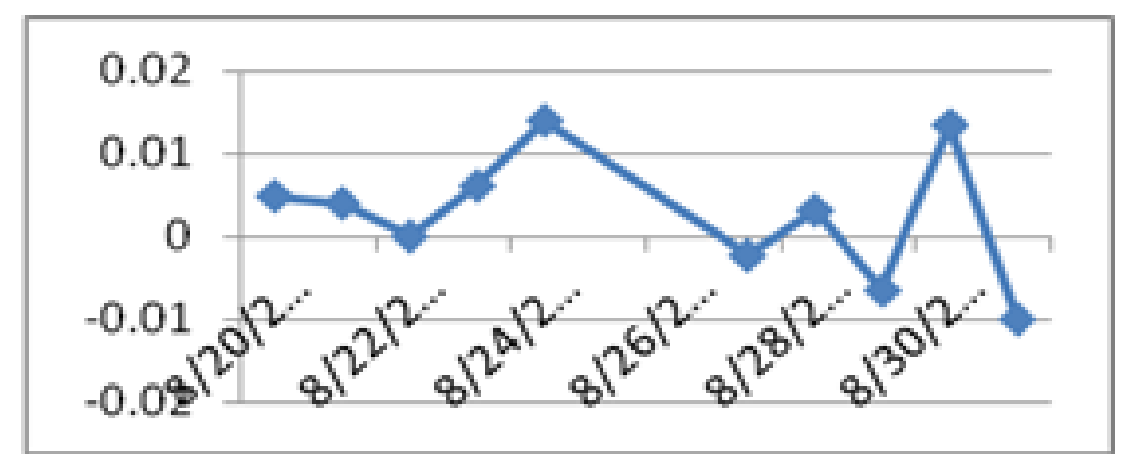

According to the picture showed the value of stock return is fluctuating. On 20 August 2018 has decreasing of 17,9\% it also happens until 22 August 2018 has decreasing of 39\%. Meanwhile on 23 August 2018 has the different average of stock return has increase from 0,00 becomes 0,015 on 24 August 2018. Whereas the decreasing of the average stock return is happened again on 24 August 2018 till 27 August 2018 which showed the data of $-0,002$. The increasing is occurred again on 28 August 2018 becomes 0,003 and decreasing again on 29 August 2018. The average of stock return in the hotel, restaurant, and tourism has significant increasing on 30 August 2018, in the last day of the ASIAN Games event has the opposite result, there is a significant decreasing until reached on $-0,01$. The fluctuating condition of the stock return could be indicated that there are many factors that are able to control stock return, so that makes the company stock prices has a changing even increasing or decreasing that in the end caused fluctuating stock return (Devy, H.S, 2017).

There is research gap and phenomena gap, the goals of the research to analyze whether occurred abnormal return in the hotel sector, restaurant and tourism of ASIAN Games phenomena. 


\section{LITERATUR REVIEW}

Event in cultural, religion, commercial, politics and or sports is able to promote the town of the host (Lim \& Downward, 2009). The winter and summer Olympics is identified as one of the mega sports event, the sports event has distintive characteristics namely combining the ceremony and festival (Gets, 1997). The research conducted by Lim \& Downward (2009) found out the Olympic event as a big event and can be said as prestigious event, the Olympic held on scale that can produce high performance in tourism, media coverage, and economic impact for the host community or goals. Although mega event has a limited duration, they have a big impact in the host country in the case of the number of tourists, Meskipun mega event mempunyai durasi yang terbatas, mereka memiliki dampak besar pada negara tuan rumah dalam hal volume turis, visitors spending awareness and the positive image of the city. It also stands out in development of infrastructure and related organization, that can be improve competency and attractiveness of society foreign people (Lim \& Downward, 2009). This research aimed to measure the economic impact of the summer Olympics in the host cities used the stock market approached. This become focused of the researcher because of the almost big city that become the host is a destination of tourism. The research showed that the prices share of the company that related to the tourism, construction and the other services can be more responsive to the selection announcement and the implementation of Olympic in the other industry such as mining or chemical which do not influence with Olympic (Lim \& Downward, 2009).

The research conducted in 2015 by Pratiwi and Yusuf based on the phenomena of world cup 2014 showed that Indonesia and Thailand have the higher reaction to the phenomena. The research use 181 sample of the company includes in ASEAN capital market. The technique of the research conducted with analyze statistics one sample t-test with quantitative data (Pratiwi \& Yusuf, 2015). On the five ASEAN countries that be observed, for 24 days observation with significant value $5 \%$ and $10 \%$. Market reaction is 14 days and 24 days of observation. According to the observation there are similarities of days that occurs the market reaction between five ASEAN countries on 14 May and 10 June.

Other research besides Pratiwi dan Yusuf (2014) about world cup event is Rusdiyanto dan Yanuar (2014). The phenomena of world cup that observed the influence to market return on Stock Exchange of Indonesia, Malaysia, Tiongkok, South Korea and Japan in the periode $2002-2014$. This research is also examine whether there is an influence in the existence of FIFA world cup event between stock market in the stock exchange on observation. On the stock exchange in Japan in 2014, Malaysia in 2010, and Indonesia in 2006 had the result showing there is a impact FIFA World Cup event to stock return (Rusdianrto yanuar, 2014). GARCH analysis model is used in determining the impact of event to stock return on the stock market. Other result is almost all the stock exchange on the observation countries have the 
impact of event to the stock market unless the stock market in Malaysia (Rusdianrto yanuar, 2014).

The research conducted by Ehrmann (2017) which analyzed the fluctuation of investor concern on the FIFA World Cup in South Africa 2010 which be held during the stock trading hours. The result showed that the numbers of trading had decreasing in $45 \%$ in the National Country played, in the other hand the volume had 55\% lower. The next reaction the market activity was influenced by the match itself. As well as the in trading activity had decreasing on 5\% (Ehrmann \& Jansen, 2017). The third finding in this study is that comovemen among national return stock and global declined to more than 20\% during the match in World Cup. Ehrmann dan Jansen (2017) concluded that the condition of market stock was followed by the development of football that is straight to the prices stock changing. The similar observation is also conducted by Vieira (2012) which saw the impact of share price to the football match result. As a representative of sentiment from researcher investor analyzed the world cup South Africa 2010 showed the prove there is no the relation yet between the match result and the next market reaction.

The research used case study conducted by Weber \& Khodr (2012) that indentified the impact of the certain events to the stock market in Qatar. Qatar market stock used a event to promote themselves and reform to improve their profile internationally and in addition to gain regional competitive advantage (Weber \& Khodr, 2012). The event made policies on economic sustainability and diversification plans and policies regarding tourism and strategies for social development. Analysis of event study that conducted produced the research appropriate with national event strategy. Other research that analyzed investor reaction to the certain event is Curatola, G., Donadelli, M., Kizys, R., \&Riedel, M. (2016), Fan, Q., \& Wang, T. (2018), Kaplanski, G., Levy, H., (2014), Kim, J. H. (2017), Fan, Q., Lei, W. and Zhang, X., (2017).

Asymetric Information

Asymmetric information is like showing an adjective that refers to a situation. The circumstances where some agents do not have the same information as investor. As in the result of economic and financial literature, the first fundamental theorem of economics from Modigliani-Militer. The assumption in theorem is that the characteristic of all products that are marketed must be equally observed by the market participant. When the assumption failed to be maintained, or is referred to as information that occurs asymmetrically, so the price becomes not reflecting on the actual or not optimal conditions in the allocation of resources. The article written by George Akerlof (1970) regarding "The market of lemons" showed why in the process of buying and selling seller knew more about the products than the buyer (or vice versa) the market could be damaged. It doesn't matter how rational someone is, or how well the market organized so asymmetric information contained a wrench in the buying and selling process. 
Asymmetric information became important to understand financial markets, this caused it was related to someone's decision to choose assets or financial portfolio (smith, 2016)

Hypothesis

A. Abnormal Return and Asian Games phenomena 2018

One of the component that reflected the value of a security is the stock price itself, and the stock price can occur abnormal return if all the information are reflected on the stock price or based on the theory found by Fama (1970) regarding market efficiency. Abnormal return is the difference between the actual return that occurs with the expected return (Jogiyanto, 2010). Abnormal return can also use as the measurement of information content (information content) from the event. One of the event will be examined the information content is the Asian Games 2018 international sports event that be held in Indonesia. The phenomena that become a concern of Asian people is the sports event awaited once for four years. In 2018 Indonesia was chosen as host of the biggest sports event preparing everything such as the venue, hotel, restaurant and the tourism. This Asian Games event indirectly will be the attraction to tourists from other countries especially Asean to visit Indonesia. This opportunity becomes the chance for the companies in hotel sector, restaurant, and tourism as he host of the sports event (Lim \& Downward, 2009) including Indonesia this chance can be used to improve the revenue which can be attraction for the investor to make request for shares of the company of the sub-sector.

Some countries like South Korea shows the increasing of economics sector on market stcok when being the host of sports event (Lim \& Downward, 2009). The existence abnormal return which significantly occurred to Athen and Seoul as the host of international sports event in the significant grade $5 \%$. In the opposite occurred in Athen when there was a cancellation the venue as a host in 1996. Indonesia and Thailand were also very reacting to the world cup event 2014, so that can be concluded that at that time non economic event or event such as sport can give the impact to stock return (Pratiwi \& Yusuf, 2015). According to the background and the previous research so the hypothesis in this research is

$\mathrm{H} 1$ = occurring the significant abnormal return on the phenomena of Asian Games 2018

$\mathrm{H} 2$ = there is the significant different abnormal return in after or before in Asian Games 2018.

\section{METHOD}

The analysis technique which used in the research is event study technique. According to Jogiyanto (2003) event study can be used as a analysis technique in examining the content of information from the certain phenomena and can be used to examining market efficiency of a half-strong form. The estimation period also used in event study analysis, determining the estimation period or estimation period refers to theory Jogiyanto and Surianto (1999) which 
revealed that there is no devinitive brenchmark for how long days that used to the estimation period. Taking this event period is intended to avoid the confounding effect from phenomena caused by too short or long will create the biased result. So that the estimation period in this research as follows:

Picture 1.2

Estimation Research Period

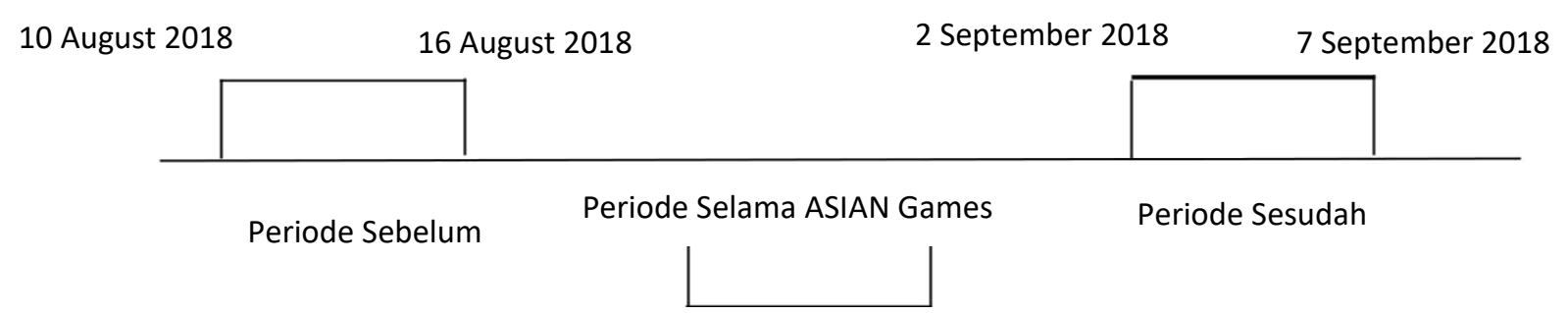

20 August $2018 \quad 31$ August 2018

a. The Source and Kind of Data

The data source of this research comes from the secondary data, that is the data which indirectly gained of the researcher (through intermediary media) or the data which gained dan noted by the other parties (Indrianto dan Supomo, 2002). The secondary data gained from the observed company or the published data for public. The data used in this research is the secondary data that gained from the base data of stock price and the volume of daily trading can be accessed from the site www.duniainvestasi.com. The research data consists stock price during the observation period.

Daily stock price data that gained is used to measure actual return, expected return, and abnormal return. While the sample used in this research used the deciding criteria such as :

1. The company which is involved in hotel sub-sector, restaurant, and tourism in Indonesia stock exchange during the observation period.

2. The company which provides the data that is necessary in the research.

\section{RESULT AND DISCUSSION}

a. Hypothesis testing

1. There is the abnormal return on the phenomenon of 2018 Asian Games.

Tests on the first hypothesis to indicate whether there is abnormal return on the phenomenon of the Asian Games 2018. Based on the research results can be explained that there is a positive abnormal return value on two days of observation before and 2 days when the Asian Games in 2018 is negative, ie at $\mathrm{t}-4, \mathrm{t}-1, \mathrm{H}-1$ and $\mathrm{t}+4(20 \%)$, so that there are abnormal returns and significant. Other than that the rest $(80 \%)$ on the day of observation are however not significant abnormal returns. Thus, there is significant abnormal returns, but not on the phenomenon of the Asian Games 2018. It can be concluded that Ho is accepted and Ha is rejected or the hypothesis that there 
is a significant abnormal returns on the phenomenon of 2018 Asian Games was rejected.The existence of the Asian Games in 2018 was well received by investors, causing abnormal return a positive value, even before the existence of the Asian Games in 2018 took place, as evidenced by the existence of a positive abnormal return value in $t-4$ that is equal to 6.388 .

The results of this analysis indicate that the presence of the Asian Games in 2018 resulted in the stock price rose, causing the value of abnormal return is positive, but not significant meaning for the Asian Games 2018 in Indonesia contains less information for the market, investors still tend to do a strategy of wait and see strategy do investors for information on the cause abnormal return is still uncertain.

2. There are significant differences of abnormal return before and after the 2018 Asian Games phenomenon

Based on test results using Wilcoxon non parametic Smirnov test can be seen that there is a difference abnormal stock returns before and after phenomena 2018 Asian Gamesbut not significant, it is proved by the significant value of $0.67>0.05$. Thus the hypothesis Ho is accepted and Ha is rejected, it means that there is no significant difference in abnormal returns before and afterphenomena 2018 Asian Games, The results of this analysis indicate that the market reaction before and after experiencing no significant difference, but the market still reacted positivelyphenomena 2018 Asian Games

b. Discussion

1. There is the abnormal return on the phenomenon of 2018 Asian Games.

The test results of the abnormal return during the period of observation, shows that there is significant abnormal return but not on the phenomenon of the Asian Games 2018. The results showed significant abnormal return and only $20 \%$ only, ie at $\mathrm{t}-4, \mathrm{t}-1, \mathrm{H}-1$ and $\mathrm{t}+4$. The rest are abnormal return but not significantly by $80 \%$. These results are also evident in the average abnormal return values greater at $t-4, t-1, H-1$ and $t+4$ is equal to 6.388, 2.352, -2983, and -2.314 With the results show that the Asian Games in 2018 was well received by investors, proven by a positive abnormal return value in the 2 days before the delivery of the Asian Games 2018. According to the law of supply and demand in economics that if demand increases it will be followed by deals an improved and prices increased as well, and vice versa, this also happens to the shares of companies included in the sub-sector of hotel, restaurant and tourism in Indonesia stock Exchange (IDX). More and more tourists from various countries to come to Indonesia to support his teams, so it will improve also benefit companies engaged in the sub-sector of hotels, restaurants and tourism. investors see that this is a positive signal that many investors are buying shares of companies sub-sector of hotel, restaurant and tourism which later resulted in rising stock prices. Abnormal return but not significantly around the observation, indicating investors who have got that information also still pursuing a strategy of wait and see, because investors do not know for sure how many tourists coming to Indonesia, and whether it can directly affect the profitability of the 
company's hotel sector and tourism significantly. Thus, it can be concluded that holding the 2018 Asian Games is lacking in information giving rise to abnormal returns, but not significant. restaurant and tourism which later resulted in rising stock prices. Abnormal return but not significantly around the observation, indicating investors who have got that information also still pursuing a strategy of wait and see, because investors do not know for sure how many tourists coming to Indonesia, and whether it can directly affect the profitability of the company's hotel sector and tourism significantly. Thus, it can be concluded that holding the 2018 Asian Games is lacking in information giving rise to abnormal returns, but not significant. restaurant and tourism which later resulted in rising stock prices. Abnormal return but not significantly around the observation, indicating investors who have got that information also still pursuing a strategy of wait and see, because investors do not know for sure how many tourists coming to Indonesia, and whether it can directly affect the profitability of the company's hotel sector and tourism significantly. Thus, it can be concluded that holding the 2018 Asian Games is lacking in information giving rise to abnormal returns, but not significant. because investors do not know for sure how many tourists coming to Indonesia, and whether it can directly affect the profitability of the hotel and tourism sector companies significantly. Thus, it can be concluded that holding the 2018 Asian Games is lacking in information giving rise to abnormal returns, but not significant. because investors do not know for sure how many tourists coming to Indonesia, and whether it can directly affect the profitability of the hotel and tourism sector companies significantly. Thus, it can be concluded that holding the 2018 Asian Games is lacking in information giving rise to abnormal returns, but not significant.

The results of this analysis in accordance with the theory put forward by Vieira (2012) which showed that the absence of a direct relationship between the arena Sports especially the world cup on the share price, the event did not make shareholder sentiment with certain activities in their respective countries become affected in managing their stocks.

2. There are significant differences of abnormal return before and after the 2018 Asian Games phenomenon

The results of the analysis using the Wilcoxon Smirnov different test proves that there is no significant difference of abnormal return before and after the Asian Games 2018. This is evidenced by the significant value of the Wilcoxon test smirnov greater than 0.05 is equal to 0.067 . The results of this analysis indicate that investors have seen any signal that tourist arrivals will come to Indonesia even before the Asian Games in 2018, so that the abnormal return before and after did not experience a significant difference.The results of this analysis also proved that there still exists asymmetric information between investors, most investors already know that Indonesia will be the arrival of tourists from various countries but some investors also have not received definitive information on how many tourists will come and direct impact on the profitability of a company sub-sector, restaurants and tourism. 
The results of testing this hypothesis supports an earlier study conducted by Ehrmann, M., \& Jansen, DJ (2017) which showed that the observation of 15 cities during the FIFA World Cup event, it does not appear any difference in abnormal returns before and after. The interest of investors to react before and after the phenomenon was minimal, so it has no effect on the stock market. Another study showed similar results, namely research conducted by Maria Vassalou and Yuhang Xing (2004) says that the announcement of default there is no significant difference between abnormal returns before and after the announcement of default.In a study of Mary Vassalou and Yuhang Xing (2004) there is a difference to the research conducted by the researchers, there are differences in the sample studied, the research Maria Vassalou and Yuhang Xing (2004) samples were used companies that defaulted on long-term debt period 1971- in 1998, while researchers used a sample of companies that defaulted in the period 2005-2014.

\section{CONCLUSION}

Based on the results of statistical analysis and data analysis that has been done, it can be concluded as follows:

1. There is a significant abnormal return but not on the phenomenon of the Asian Games 2018. This shows that investors still wait and see to the organization of the Asian Games in 2018 whether to directly affect the profitability of the hotel and tourism sector companies significantly or not, so it does not cause abnormal return significantly influence the share prices of the companies included in the sub-sector of hotel, restaurant and tourism. Thus investors can make vigilance over again before making investment transactions in the shares of companies included in the sub sector of hotel, restaurant and tourism in Indonesia Stock Exchange (IDX)

2. No difference of abnormal return before and after the Asian Games 2018. This is because, as investors look to the many tourists who have started to flock to Indonesia before the Asian Games in 2018 took place. So as not to cause a significant difference in abnormal returns in the period before and after the Asian Games in 2018.

\section{REFERENCES}

Curatola, G., Donadelli, M., Kizys, R., \& Riedel, M. (2016). Investor sentiment and sectoral stock returns: Evidence from World Cup games. Finance Research Letters, 17, 267-274.

Ehrmann, M., \& Jansen, D. J. (2017). The Pitch Rather Than the Pit: Investor Inattention, Trading Activity, and FIFA World Cup Matches. Journal of

Money, Credit and Banking, 49(4), 807-821. Fan, Q., \& Wang, T. (2018). Game day effect on stock market: Evidence from four major sports leagues in US. Journal of Behavioral and Experimental Finance, 20, 9-18.

Kaplanski, G., \& Levy, H. (2008). Exploitable Predictable Irrationality: The FIFA World Cup Effect on the U. S . Stock Market Exploitable Predictable Irrationality: The FIFA World Cup Effect on the U . S . Stock 
Market Abstract, (August).

Kaplanski, G., Levy, H., 2014. Sentiment, irrationality and market efficiency: The case of the 2010 fifa world cup. Journal of Behavioral and Experimental Economics 49, 35-43.

Kim, J. H. (2017). Stock returns and investors' mood: Good day sunshine or spurious correlation?. International Review of Financial Analysis, 52, 94-103.

Lim, C., \& Downward, P. (2009). Analysing the economic impact of the Olympics using stock market indices of host countries. 18th World IMACS Congress and MODSIM09 International Congress on Modelling and Simulation: Interfacing Modelling and Simulation with Mathematical and Computational Sciences, Proceedings, (July), 12581264.

Pratiwi, R., \& Yusuf, M. (2015). Reaksi Pasar Dalam Bentuk Return Sebelum , Selama, dan Sesudah Peristiwa Piala Dunia Tahun 2014 pada Pasar Modal Asean, 2(2), 229-237.

Rusdianrto yanuar, W. a. jatmiko. (2014). Pengaruh pada return pasar di bursa efek Indonesia, Malaysa, Korea Selatan, dan Jepang periode tahun 2002,2006,2010,2014, (1970), 1-15.

Vieira, E. F. S. (2012). Investor sentiment and market reaction: evidence on 2010 FIFA World Cup. International Journal of Economics and Accounting, 3(1), 51-76. https://doi.org/10.1504/IJEA.2012.045522

Weber, K., \& Khodr, H. (2012). Exploring the driving factors behind the event strategy in Qatar: A case study of the 15th Asian Games. International Journal of Event and Festival Management, 3(1), 81-100.

Fan, Q., Lei, W. and Zhang, X., 2017. The Impact of Sports Sentiment on Stock Returns: A Case Study from Professional Sports Leagues. Proceedings of the IEEE Global Conference on Signal and Information Processing, Symposium on Signal and Information Processing for Finance and Business 
Happy Sista Devy dan Bahrain Pasha Irawan

Halaman ini sengaja dikosongkan 